\title{
Financial Reporting Quality and Proprietary Costs
}

\author{
Daniel A. Cohen* \\ Department of Accounting and Information Management \\ Kellogg School of Management \\ Northwestern University \\ 2001 Sheridan Road, Evanston IL 60208 \\ Tel: (847) 491-2658 \\ E-mail: d-cohen3@kellogg.northwestern.edu
}

June 2002

\begin{abstract}
This study investigates the association between proprietary costs and the quality of financial reporting. Interpreting a firm's financial reporting policy as a choice of precision ("quality") for the disclosed accounting earnings, I find evidence that the higher the proprietary costs, the lower the precision ("quality") of reported accounting earnings. This is consistent with analytical work in disclosure theory which suggests that, ceteris paribus, as the proprietary cost of disclosure increases, the quality of disclosure decreases.
\end{abstract}

*This paper is based on my dissertation proposal. I would like to thank the members of my dissertation committee, Robert Korajczyk, Robert Magee, and especially Thomas Lys (chair) and Beverly Walther for their valuable comments and discussions. Aiyesha Dey, Ole-Kristian Hope, Emre Karaoglu, Elizabeth Keating, Nisan Langberg, Xiaohui Liu, and Lawrence Revsine, all provided useful suggestions. I am grateful to the Biotechnology Research Center and the Zell Center for Risk Research at the Kellogg School of Management for financial support. 


\section{Introduction}

This study investigates factors associated with the cross-sectional variation in the quality of financial reporting. Throughout this paper, I interpret a firm's choice of financial reporting policy as one that achieves a certain precision level ("quality”) for the reported accounting earnings in compliance with Generally Accepted Accounting Principles (GAAP). The "quality” of reported earnings is interpreted as the degree to which these accounting numbers more accurately represent the underlying economic fundamentals of the firm and to which extent they map into operating cash flow realizations. ${ }^{1}$ Therefore, reported earnings of higher quality are defined as earnings that better predict future operating cash flows.

The ability to predict future cash flows has been a concern of the Financial Accounting Standards Board (FASB), as it is reflected in its Statement of Financial Concepts No. 1, Objectives of Financial Reporting by Business Enterprises (1978), paragraph $37 .^{2}$ In addition, the FASB claims that earnings and its components are better indicators of future cash flows than current cash flows (FASB [1978] paragraph 44). ${ }^{3}$

The analysis in the paper is based on the assumption that firm's managers posses superior knowledge and information regarding their firm's performance relative to outside parties. As predicted by economic theory, reducing such information asymmetries can be beneficial for firms in terms of improved valuation and reduced cost of capital. Therefore, by providing information that enhances the ability of investors and other financial information users to better predict future cash flows, firms can reduce these misvaluations. However, there are also costs associated with disseminating proprietary information. For example, providing financial information of higher quality can result in

\footnotetext{
${ }^{1}$ For example, this is consistent with Mikhail et al. (2003) definition of earnings quality. They define it as (p. 1) "the extent to which a firm's past earnings are associated with its future operating cash flows." The term 'earnings quality' is vague and has different interpretations. Some users of financial statements will use the term in the context of accounting conservatism. Another interpretation focuses on persistence, where earnings of higher quality are sustainable and persist into the future. A more general interpretation of the persistence idea is suggested by tying earnings quality with predictability, claiming that earnings of higher quality are a good indicator of future earnings.

${ }^{2}$ Paragraph 37 states: “...[F]inancial reporting should provide information to help present and potential investors and creditors and other users in assessing the amounts, timing, and uncertainty of prospective cash receipts.....Thus, financial reporting should provide information to help investors, creditors, and others assess the amounts, timing, and uncertainty of prospective net cash inflows to the related enterprise.” ${ }^{3}$ Paragraph 44 states: "[ I]nformation about enterprise earnings and its components measured by accrual accounting generally provides a better indication of enterprise performance than information about current cash receipts and payments.”
} 
competitive disadvantages in the product market. Thus, firms will consider this trade-off when making decisions that affect the quality of their reported earnings and thus the predictability of future cash flows. In light of the above, the purpose of this study is to investigate the association between proprietary costs and the predictability of future cash flows and to examine whether proprietary costs constrain the quality of reported earnings.

While the theory that relates the level and/or quality of disclosure and the potential valuation benefits (e.g., a lower cost of capital) and the proprietary costs (e.g., third party concerns, especially those regarding a competitive disadvantage from disclosing information to the product market and regulators) is compelling, empirical evidence on this trade-off is scarce (see the survey article of Healy and Palepu [2001]). Harris (1998), Shin (2001), and Piotroski (2001) are examples of empirical studies that investigate the proprietary costs associated with managers' disclosure decisions. ${ }^{4}$ Harris and Piotroski focus on the firm's segment disclosure reporting decision, whereas Shin investigates the relation between product market competition and voluntary disclosure.

One of the major limitations of empirical studies on voluntary corporate disclosure is the difficulty in measuring both the level and quality of disclosure policies (Healy and Palepu [2001]). Because measuring disclosure is difficult, some studies focus only on management forecasts (e.g., Coller and Yohn [1997], Pownall, Wasley, and Waymire [1993]). Others examine disclosure ratings, for example Lang and Lundholm (1996), Healy, Hutton, and Palepu (1999), Welker (1995). The Association of Investment Management and Research (hereafter, AIMR) rankings that are often used by researchers are subjective and noisy measures of disclosure quality.

As a complementary approach to previous empirical studies that focus on disclosure quality, this study focuses on the quality of reported earnings as an interpretation of a firm's disclosure choice. Given this interpretation, I capture a broader aspect of the disclosure policy decision compared to previous empirical studies. By doing so, I provide a link between the quality of accounting information, as interpreted by its precision, and the relative proprietary costs related to such a disclosure policy decision.

\footnotetext{
${ }^{4}$ There are other studies that investigate the association between disclosure decisions and proprietary costs, but they are very context-specific. For example, Scott (1994) uses as a proxy for proprietary costs strike incidences and other labor associated variables when examining how these proprietary costs are associated with pension disclosures of Canadian firms.
} 
The results of this study suggest that the higher the proprietary costs, (as proxied by realized margins, capital intensity, and industry concentration), the lower the quality of earnings and thus the ability to accurately predict future cash flows. These results hold both in a pooled and a firm-specific analysis. In particular, the findings suggest that the less competitive is the industry, the more difficult it is to predict future cash flows. The tenor of my results is consistent with previous empirical studies, specifically Harris (1998) and Piotroski (2001). The results of this study extend the findings of earlier studies that focused only on specific disclosure decisions, for example segment disclosures, rather than examining the firms’ overall disclosure policy decision.

This study contributes to the accounting literature in several aspects. First, I suggest a link between a firm's financial disclosure reporting policy and the proprietary costs associated with such a decision. Specifically, I interpret the disclosure policy as a choice of precision for the disclosed accounting earnings which affects the ability to accurately predict future operating cash flows. This approach complements previous empirical studies that used different measures of disclosure levels/quality. Second, by identifying the proprietary costs associated with the cross-sectional variation in cash flow predictability, I provide evidence on some of the factors that partly account for this crosssectional variation. This extends our understanding of why firms do not provide financial information of the highest quality.

Section 2 of this study provides a literature review and presents the theoretical background on the association between proprietary costs and disclosures decisions. Section 3 describes the hypothesis development and the empirical model. Section 4 presents the sample selection criteria and provides descriptive statistics. Empirical results and additional analyses are presented in Section 5. Section 6 concludes and presents directions for future research.

\section{Relation to prior research}

Several studies, both analytical asset pricing models and empirical research, investigate the link between levels of disclosure and valuation, focusing generally on the firm's cost of capital. It has been shown that a firm with increased levels of disclosure reduces the cost of equity capital that arises from information asymmetries either between the firm and its stockholders, or between potential traders in the firm's shares. Examples 
of theoretical work in this area are Copeland and Galai (1983), Glosten and Milgrom (1985), and Diamond and Verrecchia (1991). Diamond and Verrecchia (1991) suggest that higher disclosure reduces the amount of information revealed by a large trade in a firm's securities, thus reducing the negative price impact that is associated with such large trades. In this scenario, investors would have larger positions in a particular firm's securities; there would be a higher demand for the firm's securities, which increases the price of the firm's stock, thus reducing the cost of equity capital.

Empirical work by Amihud and Mendelson (1986) shows that the cost of equity capital is higher for stocks with a higher bid-ask spread because investors demand to be compensated for the added transaction costs. The authors suggest that firms that provide more private information can reduce the adverse selection component of the bid-ask spread and thus reduce their cost of equity capital.

In an empirical study, Botosan (1997) claims that higher disclosure enhances stock market liquidity, which reduces the cost of equity capital either through reduced transaction costs or increased demand for the firm's stocks. She finds that for manufacturing firms that have low security analyst following, there is a negative association between a self-constructed index of disclosure level and the cost of equity capital. It had also been found that firms providing additional segment disclosures have an increase in the market's capitalization of their earnings, which is consistent with having a lower cost of equity capital (Healy and Palepu [2001]).

In a related empirical study that examines disclosures policies, Sengupta (1998) provides evidence similar to Botosan's (1997) results for the cost of the firm's debt. Similar to other empirical studies on disclosure policies (e.g., Lang and Lundholm [1993], and Healy, Hutton and Palepu [1999]), Sengupta (1998) uses AIMR scores as a measure of disclosure quality. He shows that firms with higher AIMR scores have a lower interest cost of issuing debt. Welker (1995) finds that firms with higher levels of disclosure have lower information asymmetry as proxied by bid-ask spreads. Healy, Hutton and Palepu (1999) find that firms with sustained improvements in analysts' ratings of disclosure quality (AIMR scores), experience increase in stock liquidity, analyst following, institutional ownership, and stock performance. Leuz and Verrecchia (2000) show that German firms adopting a high-quality reporting regime by switching to 
international reporting standards exhibit lower information asymmetry, as reflected by lower bid-ask spreads and higher trading volume.

In addition to the literature that investigates the benefits associated with disclosure strategies, a complementary branch of analytical research examines the costs, especially the proprietary ones, associated with disclosure decisions. Models such as Dye (1985, 1986), Verrecchia (1983, 1990), Darrough and Stoughton (1990), Wagenhofer (1990), and Hayes and Lundholm (1996), show that, all things equal, the probability of disclosure decreases as the associated proprietary costs increase. Some of these proprietary costs are mainly third party constraints - firms bear the costs of competitive disadvantage from disclosing information to their competitors and regulators, bargaining disadvantages with both suppliers and consumers, and litigation that might follow informative disclosure. $^{5}$

As Fields et al. (2001) point out, both the Botosan (1997) and Sengupta (1998) studies, although providing interesting empirical insights, suffer from some deficiencies. A major deficiency identified by the authors is that the analysis presented in these studies does not consider what the related costs of higher disclosure quality are. This claim, among others, motivates examining the cost side of disclosure policy choices.

In an analytical study, Wagenhofer (1990) suggests that on the one hand, the firm wishes to maximize its market value, but on the other hand, it wishes to deter entry of a potential competitor and to incur minimum political costs (i.e., regulatory related costs). Wagenhofer shows that although there is always a full-disclosure equilibrium, there might exist partial-disclosure equilibria, which depend on the information to be disclosed, the level of political costs, and the probability that a competitor will enter the product market. Baiman and Verrecchia (1996) consider a model in which both the costs and benefits of disclosure are taken into consideration. They show that there exists a tradeoff, for example, more disclosure reduces the cost of capital but also reduces the manager's profits from inside trading.

Addressing some of the concerns raised in Fields et al. (2001) regarding the costs associated with disclosure choices, Harris (1998) and Piotroski (2001) are examples of empirical studies that investigate the effects of proprietary costs on disclosure levels,

\footnotetext{
${ }^{5}$ Other costs related to disclosure are the costs of developing and presenting financial information. Although these costs should not be ignored, I focus mainly on third party related costs.
} 
examining only one dimension of the disclosure decision - discretionary segment disclosure. Whereas Harris (1998) focuses only on the cost side, Piotroski (2001) examines also valuation benefits related to segment disclosure reporting. Harris (1998) examines the effect of competition on a firm's segment disclosure decision and finds that in industries that are less competitive, segment disclosure is less likely to occur. Harris' (1998) disclosure measure, a binary variable measuring a decision to use segment reporting, captures only a specific type of firms that prefer this specific channel of disclosure among the set available to the firm. As Shin (2001) correctly points out, focusing only on segment disclosure as a medium of disclosure has some limitations. For example, firms that focus only on one product do not have much discretion regarding the disclosure of information, impairing a segment disclosure decision as accurately representing a voluntary disclosure decision.

While Botosan and Harris (2000) focus on how frequently firms disclose segment information, Piotroski (2001), using a self-constructed measure of disclosure, focuses on the fineness-coarseness dimension of the segment disclosure decision. He finds that segment reporting fineness is negatively related to proprietary cost factors and positively related to variables that proxy for potential valuation benefits from increased disclosure.

Shin (2001) is the only empirical study I am aware to date that tests empirically the effect of the nature of product market competition on the levels of voluntary disclosure. Shin does not examine other proprietary costs associated with disclosure, such as a potential threat of future competition, and political costs that affect disclosure decisions. He finds that the level of voluntary disclosure depends on the strategic interaction setting in the product market: capacity competition drives firms to disclose more, whereas price competition drives firms to disclose less. Although this paper presents interesting results and explicitly investigates the effects of product market competition on firms' voluntary disclosures, the voluntary disclosure levels are measured by the AIMR scores, which as previously mentioned, introduce noise and measurement errors in the research design which make the results difficult to generalize. Furthermore, Shin examines only a specific type of proprietary cost which is related to current product market competition, without focusing on other proprietary costs such as vulnerability of existing firms to future competition. 


\section{Hypothesis development and empirical model}

\subsection{Factors Determining Cash Flow Predictability}

One of the factors that determine the ability to accurately predict a firm's future cash flows is the quality of the financial information disclosed by the firm. Focusing on an informational perspective, the financial statements provide only a portion of the total value-relevant information necessarily to predict a firm's future performance. Given its significant portion in the information mix, I focus on the precision of the accounting information disclosed in the financial reports as an important ingredient in enhancing the ability to accurately predict the firm's cash flows. I assume that the choice of earnings precision is not determined exogenously; it is rather a choice variable for the firm which affects the predictability of future cash flows. ${ }^{6}$

By analyzing the objective function of the firm, both benefits and costs associated with the precision of the accounting numbers reported by the firm can be identified. Valuation benefits stem from the fact that a firms' decision to provide a high level of disclosure could decrease information asymmetries between managers and investors, and within investors and thus lower the cost of issuing equity capital and debt.

On the other hand, given that there is a potential threat of a competitor entering the product market, or the existing competitors may use the proprietary information against the firm, managers will be reluctant to provide information of high quality. Providing such information increases the likelihood of a potential entry or helps the existing competitors in the product market. If the proprietary costs outweigh the market valuation benefits, the firm will commit to provide a lower quality of disaggregated earnings, which will be less informative and will impair the ability to accurately predict future cash flows. I conjecture that the level of cash flow predictability given the quality of earnings is negatively associated with proprietary cost proxies.

\footnotetext{
${ }^{6}$ A different interpretation of this observation is that managers' choice of earnings precision is some kind of earnings management, specifically smoothing earnings over time. Trueman and Titman (1988) explore conditions under which firms will choose to smooth earnings to increase their precision (i.e., lower their variance). They claim that by smoothing earnings, managers are able to reduce the estimate of various claimants of the firm about the volatility of its earnings process, which lowers their assessment of the probability of bankruptcy. This is thought to be beneficial for the firm since it lowers the firm's cost of borrowing.
} 


\subsection{Proprietary Costs}

Were there no economic forces preventing firms from fully disclosing information and/or providing information of the highest quality, we would expect firms, given the benefits of higher quality of disclosure, to choose to provide the highest quality of financial information. As has been suggested by Fields et al. (2001), this is not the case and there are some costs involved. Therefore, when investigating the factors determining a firm's reporting strategy decision, the associated costs, especially the proprietary ones, have to be taken in consideration. ${ }^{7}$

As analytical work suggests, firms' decisions to provide information to capital markets participants take in consideration that such information might affect their competitive position in the product markets (for example, Dye [1985,1986], Verrecchia [1983], Darrough and Stoughton [1990], Wagenhofer [1990], Newman and Sansing [1993], Gigler [1994], Baiman and Verrecchia [1996], Hayes and Lundholm [1996]). Given the presence of competitors and the likelihood of potential entrants to the product market, there are proprietary costs involved in the decision to disclose information. Although extensive theoretical models address the relation between the nature of competition in the product market and disclosure decisions, the predictions are mixed. For example, if managers can protect excess profits by not providing information, then following Hayes and Lundholm (1996), if higher margins are more likely to occur in less competitive settings, then their model predicts less disclosure in less competitive industries. On the other hand, some theoretical models such as Newman and Sansing (1993) and Gigler (1994) show that the levels of disclosure may increase as proprietary costs are higher when managers can report untruthfully.

Proprietary costs are not the only factors that influence a firm's decision regarding the quality of its financial information and level of future cash flow predictability. As Watts and Zimmerman (1986) claim, firms, especially large ones, may be concerned about potential political costs that may arise from non-disclosure, which affects the reporting decision strategy. It is likely that political concerns, as reflected in expected future regulatory intervention, creates incentives to make the stream of reported earnings as less volatile as possible, which translates in a better ability to predict the future

\footnotetext{
7 There exist other costs associated with both increasing and decreasing disclosure, for example litigation costs, which I do not explicitly address in this current version of the study.
} 
performance of a firm. Therefore, large firms will have an incentive to reduce the variability of reported earnings, thus implicitly enhancing the ability to accurately predict its future cash flows.

To summarize, higher precision of financial information increases the ability to accurately predict the future performance of the firm. Information of higher quality decreases the barriers to entry in the product market and thus has an adverse effect on the incumbent firm. This leads to the prediction that the level of predictability is negatively associated with propriety costs. As a caveat, it is important to point out, that I do not draw any predictions regarding causality, but test and make predictions regarding the associations between two observed phenomena.

\subsection{Proxies for proprietary costs}

Firms that are more profitable and have higher gross margins attract future competition and face higher threats of potential entrants. Thus, the proprietary cost of providing a higher level of future predictability is expected to increase as the firm's profitability, captured by its gross margin, is higher. Therefore, I conjecture that firms that have higher gross margins have lower levels/quality of disclosure which lead to a lower level of predictability. MARGIN is defined as sales revenue net of cost of goods sold, scaled by net sales.

If the barriers to entry to a product market are relatively high, the associated proprietary costs of disclosure should be lower. High capital intensity is generally interpreted as a major barrier of entry. Therefore, capital intensity is thought to be positively associated with the ability to accurately predict future cash flows. High entry costs to a market, as reflected by high capital requirements, create situations in which a large fraction of the capital costs are already sunk for the incumbent firms, but are still funds that have not been spent yet by the potential entrants. In order to capture the feature of capital intensity as a barrier to entry, the variable CAPITAL is used, which equals net property, plant and equipment scaled by total assets. I use this stock variable, instead of a flow variable such as capital expenditures, since I believe that it better captures the idea of capital intensity of a firm.

As a market is more innovative and relies more heavily on intangible knowledge, a firm should invest more in retaining its unique status and preserve future opportunities. Given that these future opportunities are positively associated with proprietary costs, I 
expect that GROWTH, which equals the current year's percentage change in sales, proxies for future opportunities that the firm needs to protect, will be negatively associated with the level of future predictability.

An interesting empirically testable question is how exactly does the nature of competition in the product market affect the decision to provide information of high quality. Theoretical models provide different predictions regarding this issue. For example, Dye (1985) presents a model in which firms may be concerned about whether and how their proprietary information is disclosed in their financial reports. If potential competitors' decisions to enter the product market are determined in part by the proprietary information provided by the incumbent firm in its financial statements, managers of those firms will be reluctant to release proprietary information that may affect their firm's future earnings prospects. ${ }^{8}$

Verrecchia (1983) suggests that competition in the product market discourages full disclosure, whereas Darrough and Stoughton (1990) reach almost the opposite conclusion. Verrecchia (1983), identifying an exogenous cost of disclosure, focuses on post-entry competition, when firms in a particular industry are already competing, and the current competitors might adversely use the information provided. Darrough and Stoughton (1990), on the other hand, identifying an endogenous cost of disclosure, focus on pre-entry competition, when a potential entrant is concerned whether to enter the product market or not. To try and capture these different notions of competition, I measure the concentration rate of each industry by using the HERFINDAHLHIRSCHMAN INDEX. I calculate the HERFINDAHL-HIRSCHMAN INDEX as $H 1=\sum_{i=1}^{n}\left[s_{i} / S\right]^{2}$, where $s_{i}$ is the firm's sales, $S$ is the sum of sales for all firms in the industry (defined by the 2-digit SIC code), $\frac{S_{i}}{S}$ is the market share of firm $\mathrm{i}$, and $\mathrm{n}$ is the number of firms in the industry. This index takes into account the relative size and distribution of the firms in a market and approaches zero when a market consists of a large number of firms of relatively equal size (a situation close to perfect competition). The index increases both as the number of firms in the market decreases and as the

\footnotetext{
${ }^{8}$ As Dye (1985) points out, there may be other interpretation to the accounting choice model presented in his paper. Firms may be concerned about the possible reactions of other third parties entities to its financial reports, such as labor unions, suppliers of inputs, governmental agencies, and other regulators.
} 
disparity in size between those firms increases. The higher the index, the higher the potential for the exercise of market power.

On the one hand, it should be noticed that a higher concentration ratio proxies for monopoly rents. On the other hand, this may be one of the reasons why the industry is highly concentrated. Thus, the concentration ratio might be a proxy for high entry costs (high barriers to entry). Given the controversy among different analytical models, I do not have a specific prediction on the association between the level of current competition as captured by the concentration ratio and the level of future cash flows predictability.

Firms will be willing to provide high quality information if they have any concerns about potential political costs (Watts and Zimmerman [1986]) associated with providing low quality information. This leads to hypothesize that earnings quality (that is, predictability of future cash flows) is positively associated with expected political costs. I use firm size as a proxy for political costs, and expect a positive relation between size and the level of predictability. The size proxy is defined as the natural logarithm of market value of equity; I use the natural logarithm of market value in order to capture nonlinearities between my empirical measure of predictability and firm size. Although the size variable is used as a proxy for political costs, size has been identified through the literature as positively associated with disclosure policies. Given the empirical evidence on this association, the exclusion of this variable from the regression equations will impair the interpretation of the results.

I include the firm's market-to-book ratio as a control variable in order to capture the extent to which firms' financial statements are informative about the underlying business (Tasker [1998]). The firm's market-to-book ratio can be interpreted also as a proxy for growth opportunities (e.g. Barth et al. [2001b]). In the context of this study, it is expected that firms with greater growth opportunities have greater proprietary costs. Under both interpretations of the firm's market-to-book ratio, I expect that a higher ratio will be associated with a lower level of cash flow predictability. For completeness, it should be noticed that there exist other interpretations of the market-to-book ratio, for example as a proxy for accounting conservatism. This introduces a limitation in the sense that market-to-book ratios might not reflect variation in financial statement informativeness. For example, if the accounting numbers are very precise and accurate but conservative, a firm might have a high market-to-book ratio, and yet its accounting 
information would be very informative regarding the underlying economics of the firm. Therefore, this works against finding a negative relation between the market-to-book ratio and cash flow predictability as previously suggested.

\subsection{Empirical model}

\subsubsection{Measuring the Level of Cash Flow Predictability}

I am considering the following simple setting: managers of a firm, who have an objective to maximize the expected value of their firm, commit to a certain level of precision for their earnings report before issuing its shares publicly, and release an audited annual earnings report, at date t-1. Aggregate earnings for period (t-1) and its components, i.e., cash flow from operations and accruals, are used by various parties (e.g., capital markets participants and product market current and future competitors) to predict the future cash flows of the firm, i.e., cash flows at time $t, t+1$, etc.

Analytical models (e.g., Admati and Pleiderer [2000] and Baiman and Verrecchia [1996]) focus on the precision of the information provided as a measure of its quality. The precision thus characterizes the quality of disclosure chosen by the firm's managers, and is interpreted as achieving a certain level of predictability of expected future cash flows under the flexibility and discretion permitted by GAAP. Thus, the higher the precision, the higher the quality of earnings components, which translates in a more accurate prediction of future cash flows.

To measure the level of future predictability empirically, I use two empirical measures. The first one is the absolute value of the residuals obtained from a pooled regression of future operating cash flows on previous period earnings components, i.e., cash flow from operations and accruals. The second measure uses the standard deviation of the residuals obtained from a firm-specific time-series analysis.

The absolute value of the residuals and its standard deviation reflect the magnitude of future operating cash flows unrelated to current disaggregated earnings. In the empirical analysis that follows, the absolute value of the residuals and their standard deviation are the measures of disaggregated earnings ability to accurately predict future cash flows, where lower absolute value and standard deviation represents higher quality of earnings, and higher level of cash flow predictability. The use of the second empirical measure is motivated by analytical models (Holthausen and Verrecchia [1988]) that suggest that the variance of earnings forecast errors from a time-series model (which 
corresponds to cash flows forecast errors in the context of this study), is one way to interpret the precision of some kind for the information about a firm's cash flows. While I believe that my attempt to interpret the analytical models in terms of empirically measured proxies is a valid interpretation, other interpretations such as earnings smoothing over time (Trueman and Titman [1988]) are possible and valid as well.

Motivated by previous studies which show that disaggregating earnings into its components (Fairfield et al. [1996]), and in particular disaggregating accruals into major components (Barth et al. [2001a]), the measure of earnings quality focuses on the residuals obtained from estimating the model specified in equation (1). ${ }^{9}$ In the pooled analysis the focus is on the absolute value of the residuals $\left(\left|\mathrm{e}_{\mathrm{i}, t+1}\right|\right)$, whereas in the time series firm specific specification, the measure of a firm's earnings quality is the standard deviation of the residuals $\left(\sigma_{e_{i}}\right.$ ) obtained from estimating the following model: ${ }^{10}$

$\mathrm{CFO}_{\mathrm{i}, \mathrm{t}+1}=\alpha_{0}+\beta_{1} \mathrm{CFO}_{\mathrm{i}, \mathrm{t}}+\beta_{2} \Delta \mathrm{AR}_{\mathrm{i}, \mathrm{t}}+\beta_{3} \Delta \mathrm{INV}_{\mathrm{i}, \mathrm{t}}+\beta_{4} \Delta \mathrm{AP}_{\mathrm{i}, \mathrm{t}}+\beta_{5} \mathrm{DEPR}_{\mathrm{i}, \mathrm{t}}+\beta_{6} \mathrm{OTHER}_{\mathrm{i}, \mathrm{t}}+\varepsilon_{\mathrm{i}, \mathrm{t}+1}$

where:

$\mathrm{CFO}_{\mathrm{i}, \mathrm{t}} \quad=$ Cash flow from operations for firm i at year t (Compustat item \#308);

$\Delta \mathrm{AR}_{\mathrm{i}, \mathrm{t}} \quad=$ Change in accounts receivable account (Compustat item \#2);

$\Delta \mathrm{INV}_{\mathrm{i}, \mathrm{t}} \quad=$ Change in inventory account (Compustat item \#3);

$\Delta \mathrm{AP}_{\mathrm{i}, \mathrm{t}} \quad=$ Change in accounts payable account (Compustat item \#70) plus accrued expenses (Compustat item \#153);

$\operatorname{DEPR}_{\mathrm{i}, \mathrm{t}} \quad=$ Depreciation and Amortization Expense (Compustat item \#14);

OTHER $_{i, t}=$ Net of all other accruals, calculated as EARN $-(C F O+\Delta A R+\Delta I N V-$ $\triangle \mathrm{AP}-\mathrm{DEPR})$

$\varepsilon_{\mathrm{i}, \mathrm{t}+1}=$ Error term assumed to have zero mean and constant variance.

All variables are deflated by average total assets.

The pooled specification assumes homogeneity across firms and time, constraining the coefficients to be the same for all firms and across time. A part of this

\footnotetext{
${ }^{9}$ In section 5, I provide an analysis where the dependent variable is cash flow from operations for $(\mathrm{t}+2)$, and $(\mathrm{t}+3)$.

${ }^{10}$ This specification is used because it has the highest predictive ability compared to models that include multiple lags of CF and ACCRUALS components. As Barth et al. (2001) report, this specification has a significantly more predictive ability than up to four years of lag variables.
} 
assumption is relaxed in the firm-specific time series analysis, which allows earnings quality to vary in the cross-section, but it still assumes that a firm's level of predictability is constant over the estimation period. In the firm-specific regressions using annual data, I require a minimum of 10 observations for each firm to derive the standard deviation of residuals. This requirement is likely to introduce a survivorship bias into the final sample, which impairs the ability to generalize the results for young and small firms.

\subsubsection{Future Cash Flow Predictability}

An important concern relates to the fact that there may be important industry differences across firms. For example, the ability to accurately predict future cash flows may differ by industry, implying that all else equal, there will be differences in the predictability level of future cash flows for firms in different industries. To control for industry differences in future predictability, I use as the dependent variable, industry adjusted measures, to capture a firm-specific empirical measure.

Differences across firms could influence the predictability of future cash flows. Dechow, Kothari and Watts (1998) show that the predictive ability of earnings for future cash flows depends on the firm's operating cash cycle. Dechow and Dichev (2001) claim that longer operating cycles induce more uncertainty, making accruals noisier and less helpful in predicting future cash flows. To examine whether the association between the predictive ability of disaggregated earnings and proxies for proprietary costs is robust to controlling for operating cycle, I include in equation (2a) the variable OC, operating cycle where $\mathrm{OC}=\frac{\left(\mathrm{AR}_{\mathrm{t}}+\mathrm{AR}_{\mathrm{t}-1}\right) / 2}{(\mathrm{Sales} / 360)}+\frac{\left(\mathrm{INV}_{\mathrm{t}}+\mathrm{INV}_{\mathrm{t}-1}\right) / 2}{(\mathrm{COGS} / 360)}$, and is measured in days. Therefore, $\mathrm{I}$ include the operating cycle variable in the analysis to capture variation in future cash flow predictability that is not associated with the proprietary cost proxies included in the empirical specification.

Taken together with the proprietary cost proxies identified in the previous section, the following pooled cross-section and time-series specification is estimated:

$$
\begin{aligned}
\left|e_{i, t+1}\right|=\phi_{0} & +\phi_{1} \text { SIZE }_{i, t}+\phi_{2} \text { MARGIN }_{i, t}+\phi_{3} \text { CAPITAL }_{i, t}+\phi_{4} \text { GROWTH }_{i, t}+\phi_{5} \text { H1 }_{i, t}+ \\
& +\phi_{6} \mathrm{OC}_{i, t}+\phi_{7} \text { MKT }_{-} \mathrm{BK}_{\mathrm{i}, t}+\xi_{i, t+1}
\end{aligned}
$$

where: 
$\left|e_{i, t+1}\right|=\quad=$ Industry adjusted absolute value of residuals obtained from estimating equation (1);

SIZE $_{\mathrm{i}, \mathrm{t}}=$ Natural logarithm of market capitalization at the end of the fiscal year (year t), calculated as the closing price at fiscal year-end times the number of shares outstanding at fiscal year-end (Compustat item \#199 times Compustat item \#25);

MARGIN $_{\mathrm{i}, \mathrm{t}} \quad=$ Gross margin percentage, calculated as the year $\mathrm{t}$ net sales (Compustat item \#12) less cost of goods sold for the year (Compustat item \#41), scaled by net sales;

CAPITAL $_{\mathrm{i}, \mathrm{t}} \quad=$ Net plant, property and equipment (Compustat item \#8) divided by total assets (Compustat item \#6).

GROWTH $_{\mathrm{i}, \mathrm{t}}=$ Current year's growth in sales, calculated as net sales for year $\mathrm{t}$ (Compustat item \#12) less net sales of year t-1, scaled by net sales for year $\mathrm{t}-1$;

$\mathrm{H1}_{\mathrm{i}, \mathrm{t}} \quad=$ The Herfindahl Index is calculated as the sum of squares of market shares in the industry. $\mathrm{H} 1=\sum_{\mathrm{i}=1}^{\mathrm{n}}\left[\mathrm{s}_{\mathrm{i}} / \mathrm{S}\right]^{2}$, where $\mathrm{s}_{\mathrm{i}}$ is the firm's sales and $\mathrm{S}$ is the sum of sales for all firms in the industry (defined by the 2-digit SIC code), and $\mathrm{n}$ is the number of firms in the industry;

$\mathrm{OC}_{\mathrm{i}, \mathrm{t}}=$ Operating Cycle for firm $\mathrm{i}$ at time $\mathrm{t}$, measured in days as $\frac{\left(\mathrm{AR}_{\mathrm{t}}+\mathrm{AR}_{\mathrm{t}-1}\right) / 2}{(\mathrm{Sales} / 360)}+\frac{\left(\mathrm{INV}_{\mathrm{t}}+\mathrm{INV}_{\mathrm{t}-1}\right) / 2}{(\mathrm{COGS} / 360)}$, where $\mathrm{AR}$ is the firm's accounts receivable, and INV is the firm's inventory;

MKT_ $\mathrm{BK}_{\mathrm{i}, \mathrm{t}}=$ Market-to-Book ratio, where market value of equity is calculated as the closing price at fiscal year-end times the number of shares outstanding at fiscal year-end (Compustat item \#199 times Compustat item \#25), divided by the book value of common equity (Compustat item \#60).

$\xi_{\mathrm{i}, \mathrm{t}+1} \quad=$ Error term assumed to have zero mean and constant variance.

In the firm-specific time series analysis, equation (2b) is estimated. In equation (2b), the dependent variable is the standard deviation of the residuals obtained from 
estimating equation (1) for each firm in the sample. The explanatory variables are defined as in equation (2a), but are averaged across time for each firm:

$$
\begin{aligned}
\sigma_{\mathrm{e} i}=\phi_{0} & +\phi_{1} \mathrm{SIZE}_{\mathrm{i}}+\phi_{2} \text { MARGIN }_{\mathrm{i}}+\phi_{3} \text { CAPITAL }_{\mathrm{i}}+\phi_{4} \mathrm{GROWTH}_{\mathrm{i}}+ \\
& +\phi_{5} \mathrm{H}_{\mathrm{i}, \mathrm{t}}+\phi_{6} \mathrm{OC}_{\mathrm{i}}+\phi_{7} \mathrm{MKT}_{-} \mathrm{BK}_{\mathrm{i}}+\xi_{\mathrm{i}}
\end{aligned}
$$

\section{Data and Sample Selection}

\subsection{Sample Selection}

Table 1 summarizes the sample selection criteria. The data are from the 2000 Compustat annual industrial and research files and spans the 1987-2000 period. Previous studies (e.g. Collins and Hribar [2000], Dechow, Kothari, and Watts [1998]) document and discuss that deriving cash flow from operations from balance sheet accounts leads to potential problems such as noisy and biased estimates. The cash flow from operations reported in the statement of cash flows following SFAS No. 95 is likely to have less measurement error. Therefore, I limit my attention to this specific period since cash flow from operations (Compustat item \#308) calculated from the statement of cash flows are only available starting in 1987, following Statement of Financial Accounting Standard No. 95 (SFAS No.95). ${ }^{11}$ The earnings number used in the analysis is Compustat item \#18, earnings before extraordinary items.

I exclude all the firms that belong to SIC codes 6000-6999 (financial institutions, insurance, and real estate companies) since the cash flow predictability empirical model developed does not reflect their activities. Next, I restrict the analysis to firms that have non-missing data for assets, earnings, and cash flow form operations. I also exclude observations with sales less than $\$ 10$ million, share price less than $\$ 1$, and the most extreme one percent of cash flow from operations and earnings. This reduces the sample by 37,724 firm-year observations from an initial figure of 93,354 firm-year observations. In addition, I require firms to have at least one year of past and future cash flows, since in the first stage of the empirical analysis the dependent variable is future cash flow from operations. These criteria yield a primary sample of 32,745 firm-year observations, representing 5,845 firms.

\footnotetext{
${ }^{11}$ SFAS No.95 requires firms to present a statement for fiscal years ending after July 15, 1988. Some firms early-adopted SFAS No.95, so my sample begins in 1987. This sample selection is consistent with Barth et al. (2001).
} 


\subsection{Descriptive Statistics}

Table 2 presents descriptive statistics for the variables used in the first stage of the analysis (equation (1)). Consistent with prior studies (Barth et al. [2001a], and Sloan [1996]) the means and medians of earnings and cash flow from operations are positive, and those of total accruals, which are the difference between earnings and cash flow from operations, are negative. Mean and median of total accruals are negative since they include depreciation and amortization. The table also reveals that current accruals such as the change in accounts receivable and inventory are smaller in magnitude and are more volatile than depreciation, which is a long-term accrual. These findings are consistent with prior studies, e.g., Sloan (1996).

Table 3 provides Pearson (above the diagonal) and Spearman (below the diagonal) correlations between the variables used in estimating equation (1). ${ }^{12}$ EARN which is earnings before extraordinary items (Compustat item \#18), is significantly (at a 1\% significance level) positively correlated with both ACCRUALS and CFO, where CFO is cash flow from operating activities (Compustat item \#308), and ACCRUALS is the difference between EARN and CFO. ACCRUALS and CFO are significantly (at a 1\% significance level) negatively correlated. The accrual components are significantly correlated with both EARN and CFO, and in general they are also correlated with each other. The correlations among the variables presented in Table 3 are consistent with those presented in Table 1 Panel B of Barth et al. (2001a).

Table 4 presents descriptive statistics for the variables used in the second stage of the analysis. The variable OC, operating cycle, has a mean of 145 days and a standard deviation of 112 days. This indicates that the majority of the firms in the sample have an operating cycle of less than one year. This finding is consistent with the fact that most accruals reverse within one year (Dechow and Dichev [2001]). The sample consists of sizable firms with average market value of \$959 million and a median of \$149 million. The mean (median) of $\mathrm{H} 1$ (the concentration ratio) is 0.25 (0.15), indicating that the sample represents rather competitive industries, but with large variation across the sample.

\footnotetext{
${ }^{12}$ Although EARN is not used directly in estimating equation (1), it is included in Table 3 to provide consistency with prior research.
} 


\section{Empirical Results}

\subsection{Deriving the Empirical Measure of Predictability of Future Cash Flows}

Table 5 presents regression summary statistics for estimating equation (1), which is estimated over time and across firms in order to obtain the residuals that are used as the empirical measure of the ability to accurately predict future cash flow from operations:

$$
\mathrm{CFO}_{\mathrm{i}, t+1}=\alpha_{0}+\beta_{1} \mathrm{CFO}_{\mathrm{i}, \mathrm{t}}+\beta_{2} \Delta \mathrm{AR}_{\mathrm{i}, \mathrm{t}}+\beta_{3} \Delta \mathrm{INV}_{\mathrm{i}, \mathrm{t}}+\beta_{4} \Delta \mathrm{AP}_{\mathrm{i}, \mathrm{t}}+\beta_{5} \mathrm{DEPR}_{\mathrm{i}, \mathrm{t}}+\beta_{6} \mathrm{OTHER}_{\mathrm{i}, \mathrm{t}}+\varepsilon_{\mathrm{i}, \mathrm{t}+1}
$$

This procedure replicates the main model presented in Barth et al. (2001a). Consistent with their results, the accrual components in equation (1) and current operating cash flows are all significantly different from zero and have predicted signs. All the explanatory variables, with the exception of $\Delta \mathrm{AP}$, have a positive sign. Given the time structure of equation (1), where one of the independent variables is a lag variable of the dependent variable, I control for the apparent autocorrelation by using the Yule-Walker method for first-order autocorrelation. The correction procedure does not affect significantly the t-statistics, and the previous inferences still hold.

Table 6 presents Pearson (above the diagonal) and Spearman (below the diagonal) correlation among the variables that are used to explain the variation in cash flow predictability. As expected, the level of predictability, as measured by $\left|\mathrm{e}_{\mathrm{i}, \mathrm{t}+1}\right|$ ), the absolute value of the residuals obtained from estimating equation (1), is significantly and positively correlated with MARGIN, GROWTH and OC. On the other hand, $\left.\left|\mathrm{e}_{\mathrm{i}, t+1}\right|\right)$, is significantly negatively correlated with SIZE and CAPITAL. Consistent with some theoretical predictions, the level of competition, as captured by the concentration ratio $\mathrm{H} 1$, is positively associated with deficiencies in predicting future operating cash flows accurately. This suggests that the higher the concentration ratio, the less competitive the industry is and the higher the likelihood that competitors can engage in anti-competitive activity, the lower the ability to accurately predict future cash flows. This result is inconsistent with disclosure models that predict that firms respond to higher levels of competition by providing less information, e.g., Verrecchia (1983).

The univariate analysis suggests that the level of future cash flow predictability, as empirically measured by $\left|e_{i, t+1}\right|$, and different proxies of proprietary costs are negatively associated, implying that the higher the proprietary costs proxies, the lower the 
ability to accurately predict future cash flows, based on the disaggregated earnings components as disclosed in the firm's financial reports.

\subsection{Results: Cross-Sectional Determinants of Future Cash Flow Predictability}

Focusing on a multivariate analysis, Table 7 presents the results from estimating equation (2a), where the dependent variable is the industry adjusted absolute value of the residuals obtained from estimating equation (1). As with the first stage estimation, the analysis is based on a pooled cross-section and time-series regression. The results in Column A are consistent with the predictions regarding the negative association between proprietary cost proxies and cross-sectional differences in the level of future cash flows predictability.

The variables MARGIN, GROWTH, and OC display significant (at 1\% significance level) positive relation with $\left|\mathrm{e}_{\mathrm{i}, \mathrm{t}+1}\right|$, while CAPITAL and SIZE have a significant negative relation with $\left|\mathrm{e}_{\mathrm{i}, \mathrm{t}+1}\right|$. These findings suggest that larger and more capital intensive firms are providing financial information that predicts future cash flows with a higher precision. One interpretation of this finding is that firm size, as well as capital intensity, can act as a barrier to entry for future competitors in the product market. Therefore, such firms incur less proprietary costs in providing financial information, as reflected in the reported disaggregated earnings which are more informative regarding their future performance. It is important to point out that the negative coefficient on SIZE is consistent with different interpretations, such as a political cost interpretation. A larger firm prefers to provide more informative financial information anticipating that the likelihood of incurring political costs increases by not choosing such a reporting strategy.

An additional interpretation of firm size is that it proxies for the firm's information environment, where these results indicate that the larger the firm is, the more accurately one can predict its future cash flows. This is consistent with previous research documenting a positive relation between firm size and disclosure policy decisions (e.g., Lang and Lundholm [1993]). Another interpretation for the observed sign on the size coefficient is that there are some firm characteristics omitted from the model that are related to the quality of a firm's accounting numbers, such as that larger firms are followed by more analysts. 
The significant coefficient on MARGIN implies that firms that are more profitable (as reflected in higher realized margins) have higher proprietary costs that are associated with a lower level of predictability. The positive significant coefficient on H1, which captures the level of competition within a particular industry (the level of concentration), is consistent with the interpretation of the positive coefficient of MARGIN, i.e., in less competitive industries, the lower the quality of financial information. In other words, in more competitive environments, higher quality of financial information prevails. These results are consistent with theory models predicting less disclosure in less competitive markets (e.g., Hayes and Lundholm [1996]). The tenor of the results presented is consistent with empirical studies examining the relation between segment disclosures and proprietary costs associated with product market competition and other proprietary cost proxies, such as Harris (1998) and Piotroski (2001).

Taken together, the results suggest that firms with higher proprietary costs provide accounting information of lower quality, i.e. earnings with lower precision, after controlling for variability in future predictability which is not related to proprietary costs.

\subsection{Firm-Specific Analysis}

In this section I present results from estimating equation (1) in firm-specific timeseries regressions. This methodology relaxes the assumption that constrains the relation between future cash flows and disaggregated earnings to be the same for all firms. In the first stage, equation (1) is estimated for each firm that has more than 10 annual observations. This requirement reduces the number of firms included in the analysis to 1,255. Having obtained the residuals from estimating equation (1), I calculate for each firm the standard deviation of these residuals $\left(\sigma_{\mathrm{e}_{\mathrm{i}}}\right) \cdot \sigma_{\mathrm{e}_{\mathrm{i}}}$ is the empirical measure of earnings precision, and is interpreted as the ability to accurately predict future operating cash flows, where a higher standard deviation suggests lower predictability. In the second stage, equation (2b) is estimated in a cross-section, where for each firm the explanatory variables were averaged across time.

$$
\begin{aligned}
\sigma_{\mathrm{ei}}=\phi_{0} & +\phi_{1} \mathrm{SIZE}_{\mathrm{i}}+\phi_{2} \text { MARGIN }_{\mathrm{i}}+\phi_{3} \text { CAPITAL }_{\mathrm{i}}+\phi_{4} \mathrm{GROWTH}_{\mathrm{i}}+ \\
& +\phi_{5} \mathrm{H}_{\mathrm{i}, \mathrm{t}}+\phi_{6} \mathrm{OC}_{\mathrm{i}}+\phi_{7} \mathrm{MKT}_{-} \mathrm{BK}_{\mathrm{i}}+\xi_{\mathrm{i}}
\end{aligned}
$$


Table 8 presents the results of the firm-specific analysis. Column A and B report the results of estimating equation (2b) which are consistent with the overall relations observed in the pooled analysis.

\subsection{Additional Analyses}

The findings thus far are based on predicting one-year-ahead cash flows, whereas prior research predicts cash flows for future periods as well. To examine the ability of current disaggregated earnings to predict cash flows more than one year ahead, I repeat the analysis by estimating equation (1) and use $\mathrm{CF}_{\mathrm{t}+2}$ and $\mathrm{CF}_{\mathrm{t}+3}$ as the dependent variable.

Table 9 presents the findings for repeating the pooled analysis. The results suggest that the proprietary cost proxies are all significant in explaining the variation in cash flow predictability more than one year ahead. OC is not significant, as observed in Column B. This is not quite surprising given the fact that descriptive statistics on the operating cycle suggest that the majority of the firms in the sample have an operating cycle of less than one year, which is consistent with the fact that most accruals reverse within one year.

Table 10 reports the results for the firm-specific analysis, where the dependent variable is the standard deviation of the residuals obtained from predicting cash flows two and three periods ahead. Although there is a decrease in explanatory power as the prediction horizon increases, the results are in general consistent with the previous analysis. The coefficient on OC is not significant as in the pooled analysis, and the interpretation is as before.

\section{Summary, Conclusions, and Future Research}

Analytical models of disclosure suggest that firms consider the costs associated with providing proprietary information, predicting that such disclosures can damage the firm's competitive position in the product market (e.g., Dye [1985, 1986], Verrecchia [1983], Darrough and Stoughton [1990], and Wagenhofer [1990]). This has been referred to as the proprietary cost hypothesis throughout the accounting literature (Healy and Palepu [2001]).

Although the theoretical work in this field has been extensive, empirical evidence on the proprietary cost hypothesis has been provided only for specific disclosure contexts 
(e.g., segment reporting and voluntary disclosures). Interpreting the firm's disclosure decision as a choice of precision for the disclosed accounting earnings that affects future performance predictability, this paper provides evidence on the association between proprietary cost proxies and the ability to predict future cash flows. In a sample that spans 1987-2000, cash flow predictability is shown to be negatively associated with proprietary cost proxies. Specifically, I find that when the barriers to enter an industry are high, suggesting that proprietary costs are lower, the level of predictability of cash flows is higher. When the firm needs to protect future assets and firm specific future opportunities, proprietary costs are high and the predictability of future cash flows is low.

Assuming that the competition in the product market is among existing firms, the results suggest that less competition, as reflected both in higher realized margins and higher concentration ratios, is negatively associated with cash flow predictability.

There are some limitations to the analysis presented in this study. I did not explicitly model and estimate the valuation benefits associated with the ability to predict future cash flows, for example how the firm's cost of capital is associated with cash flow predictability, but focused only on the cost side. This is to be done in future work. A second limitation is the potential endogeneity problem. A firm might consider the expected proprietary costs and/or the expected changes in its cost of capital (or reducing its information asymmetry) when it makes its decision regarding its earnings quality. In future work, I will include proxies that capture explicitly the valuation benefits from increased quality of earnings and I will simultaneously test the relation between the ability to accurately predict future cash flows and the valuation benefits and proprietary costs. 


\section{References}

Admati A. and P. Pfleiderer. "Forcing Firms to Talk: Financial Disclosure Regulation and Externalities.” The Review of Financial Studies 13 (2000): 479-519.

Amihud, Y. and H. Mendelson. "Asset Pricing and the Bid-Ask Spread.” Journal of Financial Economics 17 (1986): 223-249.

Atiase, R. "Predisclosure Information, Firm Capitalization, and Security Price Behavior Around Earnings Announcements.” Journal of Accounting Research 23 (1985): 21-36.

Baiman, S. and R.E. Verrecchia. "The Relation among Capital Markets, Financial Disclosure, Production Efficiency and Insider Trading.” Journal of Accounting Research 34 (1996): 1-22.

Barth, M., D.P. Cram, and K. Nelson. "Accruals and the Prediction of Future Cash Flows.” The Accounting Review 76 (2001a): 27-58.

Barth, M., R. Kasznik, and M. F. McNichols. "Analyst Coverage and Intangible Assets.” Journal of Accounting Research 39 (2001b): 1-35.

Bhushan, R. "Firm Characteristics and Analyst Following." Journal of Accounting and Economics 11 (1989): 255-274.

Botosan, C. "Disclosure Level and the Cost of Equity Capital." The Accounting Review 72 (1997): 323-349.

Botosan, C. and M. Harris. "Motivations for a Change in Disclosure Frequency and Its Consequences: An Examination of Voluntary Quarterly Segment Disclosures.” Journal of Accounting Research 38 (2000): 329-353.

Bradshaw, M., S. Richardson, and R. Sloan. "Do Analysts and Auditors Use Information in Accruals?” Journal of Accounting Research 39(2001): 45-75.

Bricker, R., G. Previts, T.Robinson, and S. Young. "Financial Analyst Assessment of Company Earnings Quality.” Journal of Accounting, Auditing and Finance 10 (1995): 541-554.

Brown, S., M. Finn and S. Hillegeist. "Disclosure Quality and the Probability of Informed Trade.” Working Paper, Northwestern University (2001). 
Clarkson, P., J.L. Kao and G. Richardson. "The Voluntary Inclusion of Forecasts in the MD\&A Section of Annual Reports.” Contemporary Accounting Research 11(1994): 423-450.

Coller, M. and T. Yohn. "Management Forecast and Information asymmetry: An Examination of Bid-Ask Spreads.” Journal of Accounting Research 35 (1997): 181-191.

Copeland, T. and D. Galai. "Information Effects on the Bid-Ask Spread.” The Journal of Finance 36 (1983): 1457-1469.

Darrough, M., and N. Stoughton. "Financial Disclosure Policy in an Entry Game." Journal of Accounting and Economics 12(1990): 219-243.

Dechow, P. "Accounting Earnings and Cash Flows as Measures of Firm Performance: The Role of Accounting Accruals.” Journal of Accounting and Economics 18 (1994): 342.

Dechow P. and Dichev I. "The Quality of Accruals and Earnings: The Role of Accrual Estimation Errors.” Working paper, University of Michigan (2001).

Dechow, P., S.P. Kothari, and R. Watts. "The Relation between Earnings and Cash Flows.” Journal of Accounting and Economics 25 (1998): 133-168.

Diamond D. and R. Verrecchia. "Disclosure, Liquidity, and the Cost of Capital." The Journal of Finance 66 (1991): 1325-1355.

Dye, R.A. "Disclosure of Nonproprietary Information.” Journal of Accounting Research 23 (1985a): 123-145.

Dye, R.A. "Strategic Accounting Choice and the Effects of Alternative Financial Reporting Requirements.” Journal of Accounting Research 23 (1985b): 544-574.

Dye, R.A. "Proprietary and Nonproprietary Disclosures.” Journal of Business 59 (1986): 331-366.

Dye, R.A. "An Evaluation of "Essays on Disclosure" and the Disclosure Literature in Accounting.” Journal of Accounting And Economics 32 (2001): 181-235.

Dye, R.A. and S. Sridhar. “Industry-Wide Disclosure Dynamics.” Journal of Accounting Research 33 (1995): 157-174.

Easley, D. and M. O’hara. “Information and the Cost of Capital.” Working Paper, Cornell University (2001).

Fairfield, P., R. Sweeney, and T. Yohn. "Accounting Classification and the Predictive Content of Earnings.” The Accounting Review 71 (1996): 337-355. 
Feltham, G.A. and J.Z. Xie. "Voluntary Disclosure in an Entry Game with Continua of Types.” Contemporary Accounting Research (1992): 46-80.

Fields T. D., T. Z. Lys, and L. Vincent. "Empirical Research on Accounting Choice." Journal of Accounting and Economics 31 (2001): 255-307.

Financial Accounting Standards Board. Statement of Financial Accounting Concepts Number 1, Objectives of Financial Reporting by Business Enterprises. New York, NY. FASB. 1978.

Finger, C. "The Ability of Earnings to Predict Future Earnings and Cash Flow.” Journal of Accounting Research 32 (1994): 210-223.

Gigler, F. “Self-Enforcing Voluntary Disclosures.” Journal of Accounting Research 32 (1994): 224-240.

Glosten, L. and P. Milgrom. “Bid Ask and Transaction Prices in a Specialist Market with Heterogeneously Informed Traders.” Journal of Financial Economics (1985): 71-100.

Harris, M.S. “The Association between Competition and Managers' Business Segment Reporting Decisions.” Journal of Accounting Research 36 (1998): 111-128.

Hayes, R. and R. Lundholm. "Segment Reporting to the Capital Market in the Presence of a Competitor.” Journal of Accounting Research 34 (1996): 261-279.

Healy, P. M. and K.G. Palepu. "Information Asymmetry, Corporate disclosure, and the Capital markets: A review of the Empirical Disclosure Literature”, Journal of Accounting and Economics 31 (2001): 405-440.

Healy, P., A. Hutton, and K. Palepu. "Stock Performance and Intermediation Changes Surrounding Sustained Increases in Disclosure.” Contemporary Accounting Research 16 (1999): 485-520.

Holthausen, R. and R.E. Verrecchia. "The Effect of Sequential Information Releases on the Variance of Price Changes in an Intertemporal Multi-Asset Marker.” Journal of Accounting Research 26 (1988): 82-106.

Hribar, P. and D.A. Colllins. "Errors in Estimating Accruals: Implications for Empirical Research.” Working Paper, Cornell University and Iowa University (2000).

Kim, O. and R.E. Verrecchia. "Trading Volume and Price Reactions to Public Announcements.” Journal of Accounting Research 29 (1991): 302-321.

Lang, M. and R. Lundholm. "Cross-sectional Determinants of Analysts Ratings of Corporate Disclosures. “ Journal of Accounting Research 31 (1993): 246-271.

Lang, M. and R. Lundholm. "Corporate Disclosure Policy and Analyst Behavior.” The Accounting Review 71 (1996): 467-492. 
Lang, M., and J. S. Raedy, and M. Yetman. "How Representative are Cross-listed Firms? An analysis of Firm and Accounting Quality.” Working Paper University of North Carolina (2002).

Mikhail, M., B. Walther, and R. Willis. "Reactions to Dividend Changes Conditional on Earnings Quality.” Working Paper Duke University and Northwestern University (2001).

Nagarajan, N. and S. Sridhar. "Corporate Responses to Segment Disclosure Requirements.” Journal of Accounting and Economics 21 (1996): 253-275.

Newman, P. and R. Sansing. "Disclosure Policies with Multiple Users.” Journal of Accounting Research 31 (1993): 92-112.

Nissim, D. "Discussion of 'Reactions to Dividend Changes Conditional on Earnings Quality’.” Columbia University (2002).

Penman, S. and X. Zhang. "Accounting Conservatism, the Quality of Earnings and Stock Returns. ” Working Paper Columbia University (1999).

Piotroski, J. "Discretionary Segment Reporting Decisions and the Precisions of Investors Beliefs.” Working Paper University of Chicago (2001).

Pownall, G., C. Wasley, and G. Waymire. "The Stock Price Effects of Alternative Types of Management Earnings Forecasts.” The Accounting Review 68 (1993): 896-912.

Richardson, S., R. Sloan, M. Soliman, and I. Tuna. "Information in Accruals about the Quality of Earnings.” Working Paper University of Michigan (2001).

Schrand, C. and R.E. Verrecchia. "Disclosure Choice and the Cost of Capital: Evidence from Underpricing in Initial Public Offerings.” Working Paper, University of Pennsylvania (2002).

Scott, T.W. "Incentives and Disincentives for Financial Disclosure: Voluntary Disclosure of Defined Benefit Pension Plan Information by Canadian Firms.” The Accounting Review 69 (1994): 26-43.

Sengupta, P. “Corporate Disclosure Quality and the Cost of Debt.” The Accounting Review 73 (1998): 459-474.

Shin, Y. "The Effect of Product Market Competition on Corporate Voluntary Disclosure Decisions.” Working paper, Tulane University (2001).

Sloan, R. "Do Stock Prices Fully Reflect Information in Accruals and Cash Flows about Future Earnings.” The Accounting Review 71(1996): 289-315.

Tasker, S. "Bridging the Information Gap: Quarterly Conference Calls as a Medium for Voluntary Disclosure.” Review of Accounting Studies 3 (1998): 137-167. 
Trueman, B. and S. Titman. “An Explanation for Accounting Income Smoothing." Journal of Accounting Research 26 (1988): 127-139.

Verrecchia, R.E. "Discretionary Disclosure." Journal of Accounting and Economics 5 (1983): 179-195.

Verrecchia, R.E. "Endogenous Proprietary Costs Through Firm Interdependence." Journal of Accounting and Economics 12 (1990): 245-251.

Verrecchia, R.E. “Information Quality and Discretionary Disclosure.” Journal of Accounting and Economics 12 (1990): 365-380.

Verrecchia R.E. "Essays on Disclosure.” Journal of Accounting and Economics 32 (2001): 97-180.

Wagenhofer, A. "Voluntary Disclosure with a Strategic Opponent." Journal of Accounting and Economics 12 (1990): 341-363.

Watts, R.L. and J.L. Zimmerman. "Positive Accounting Theory." Prentice Hall, Englewood Cliff NJ 1986.

Welker, M. "Disclosure Policy, Information Asymmetry and Liquidity in Equity Markets.” Contemporary Accounting Research 11 (1995): 801-828. 


\section{Table 1: Derivation of Sample and Variable Definitions}

\section{Panel A: Sample Construction}

\begin{tabular}{|l|l|l|}
\hline $\begin{array}{l}\text { Firm-years with available } \\
\text { cash from operations, } \\
\text { earnings, and total assets in } \\
\begin{array}{l}\text { COMPUSTAT (1987-2000) } \\
\text { (excluding financial firms, } \\
\text { SIC codes 6000-6999) }\end{array}\end{array}$ & Firm-years & Firms \\
\hline $\begin{array}{l}\text { Exclude firm-years with } \\
\text { sales less than \$10 Million } \\
\text { and price less than \$1 }\end{array}$ & $(35,269)$ & $(3,665)$ \\
\hline $\begin{array}{l}\text { Exclude firm-years with the } \\
\text { most extreme 1\% of cash } \\
\text { from operations, earnings, } \\
\text { and total assets }\end{array}$ & $(2,455)$ & $(180)$ \\
\hline $\begin{array}{l}\text { Exclude firm-years without } \\
\text { both a lead and a lag value } \\
\text { of cash from operations }\end{array}$ & $(9,477)$ & $(1,386)$ \\
\hline $\begin{array}{l}\text { Exclude firm-years with } \\
\text { missing values in one of the } \\
\text { variables used in the first } \\
\text { stage analysis }\end{array}$ & $(13,337)$ & $(2,266)$ \\
\hline $\begin{array}{l}\text { Primary sample used in } \\
\text { analysis, after deleting firm- } \\
\text { year observations with } \\
\text { missing values in one of the } \\
\text { variables. }\end{array}$ & 32,745 & 5,845 \\
\hline
\end{tabular}




\section{Table 1 - continued}

\section{Panel B: Variable Definitions}

\begin{tabular}{|c|c|}
\hline EARN & $\begin{array}{l}\text { Income before extraordinary items and discontinued operations } \\
\text { (Compustat item\#18). }\end{array}$ \\
\hline $\mathrm{CFO}$ & Net cash flow from operating activities (Compustat item \#308) \\
\hline ACCRL & Total operating accruals, calculated as EARN - CFO. \\
\hline$\Delta \mathrm{AR}$ & Change in accounts receivable account (Compustat item \#2). \\
\hline$\Delta \mathrm{INV}$ & Change in inventory account (Compustat item \#3). \\
\hline$\Delta \mathrm{AP}$ & $\begin{array}{l}\text { Change in accounts payable account (Compustat item \#70) plus accrued } \\
\text { expenses (Compustat item \#153). }\end{array}$ \\
\hline DEPR & Depreciation and Amortization Expense (Compustat item \#14). \\
\hline OTHER & $\begin{array}{l}\text { Net of all other accruals, calculated as EARN }-(\mathrm{CFO}+\Delta \mathrm{AR}+\Delta \mathrm{INV}- \\
\Delta \text { AP-DEPR). }\end{array}$ \\
\hline MARGIN & $\begin{array}{l}\text { Gross margin percentage, calculated as the year t net sales (Compustat } \\
\text { item \#12) less cost of goods sold for the year (Compustat item \#41), } \\
\text { scaled by net sales. }\end{array}$ \\
\hline OC & Operating Cycle (in days), calculated as $\frac{\left(\mathrm{AR}_{\mathrm{t}}+\mathrm{AR}_{\mathrm{t}-1}\right) / 2}{(\text { Sales/360) }}+\frac{\left(\mathrm{INV}_{\mathrm{t}}+\mathrm{INV}_{\mathrm{t}-1}\right) / 2}{(\mathrm{COGS} / 360)}$ \\
\hline CAPITAL & $\begin{array}{l}\text { Net plant, property and equipment (Compustat item \#8) divided by total } \\
\text { assets (Compustat item \#6). }\end{array}$ \\
\hline SIZE & $\begin{array}{l}\text { Natural logarithm of market capitalization at the end of the fiscal year } \\
\text { (year t), calculated as the closing price at fiscal year-end times the } \\
\text { number of shares outstanding at fiscal year-end (Compustat item \#199 } \\
\text { times Compustat item\#25). }\end{array}$ \\
\hline $\mathrm{RD}$ & $\begin{array}{l}\text { Research and development as a percentage of sales, calculated as year t } \\
\text { research and development expense (Compustat item \#46) scaled by net } \\
\text { sales (Compustat item \#12). }\end{array}$ \\
\hline GROWTH & $\begin{array}{l}\text { Current year's growth in sales, calculated as net sales for year t } \\
\text { (Compustat item \#12) less net sales of year t-1, scaled by net sales for } \\
\text { year t-1. }\end{array}$ \\
\hline MKT_BK & $\begin{array}{l}\text { Market-to-Book ratio, where market value of equity is calculated as the } \\
\text { closing price at fiscal year-end times the number of shares outstanding at } \\
\text { fiscal year-end (Compustat item \#199 times Compustat item \#25), } \\
\text { divided by the book value of common equity (Compustat item \#60). }\end{array}$ \\
\hline H1 & $\begin{array}{l}\text { The Herfindahl Index is calculated as the sum of squares of market shares } \\
\text { in the industry. } \mathrm{H} 1=\sum_{\mathrm{i}=1}^{\mathrm{n}}\left[\mathrm{s}_{\mathrm{i}} / \mathrm{S}\right]^{2} \text {, where } s_{i} \text { is the firm's sales and } \mathrm{S} \text { is the } \\
\text { sum of sales for all firms in the industry (defined by the 2-digit SIC } \\
\text { code), and } \mathrm{n} \text { is the number of firms in the industry). }\end{array}$ \\
\hline
\end{tabular}


Table 2

Descriptive Statistics on Earnings, Cash Flow from Operations, and Accruals, Sample of 32,745 Firm-Year Observations, 1987-2000

The table reports descriptive statistics on a sample of 32,745 firm-year observations. EARN is income before extraordinary items (Compustat item \#18). CFO is cash flow from operations (Compustat item \#308). ACCRUALS are total operating accruals, calculated as EARN - CFO.

$\triangle \mathrm{AR}, \triangle \mathrm{INV}, \triangle \mathrm{AP}$ are calculated as the change in the applicable balance sheet account, accounts receivable (Compustat item \#2), inventory (Compustat item \#3), and accounts payable (Compustat item \#70) plus accrued expense (Compustat item \#153), respectively. DEPR is depreciation and amortization (Compustat item \#14). OTHER is calculated as EARN - (CFO $+\Delta$ AR $+\Delta$ INV $-\Delta$ AP-DEPR).

All of the above variables are scaled by average book value of total assets (Compustat item \#6)

\begin{tabular}{lcccc}
\hline Variable & $\mathrm{N}$ & Mean & Median & Std Dev \\
\hline EARN & 32,745 & 0.034 & 0.044 & 0.120 \\
CFO & 32,745 & 0.077 & 0.082 & 0.110 \\
ACCRUALS & 32,745 & -0.043 & -0.042 & 0.078 \\
$\Delta$ AR & 32,745 & 0.020 & 0.011 & 0.069 \\
$\Delta$ INV & 32,745 & 0.015 & 0.005 & 0.076 \\
$\Delta$ AP & 32,745 & 0.078 & 0.068 & 0.038 \\
DEPR & 32,745 & 0.049 & 0.044 \\
OTHER & 32,745 & 0.048 & 0.044 \\
\hline
\end{tabular}


Table 3

Correlation matrix between variables used in the first stage of empirical analysis

This table reports Pearson (above the diagonal) and Spearman correlations (below the diagonal). The sample is based on 32,745 firm-year observations.

EARN is income before extraordinary items (Compustat item \#18). CFO is cash flow from operations (Compustat item \#308). ACCRUALS are total operating accruals, calculated as EARN - CFO.

$\triangle \mathrm{AR}, \Delta \mathrm{INV}, \triangle \mathrm{AP}$ are calculated as the change in the applicable balance sheet account, accounts receivable (Compustat item \#2), inventory (Compustat item \#3), and accounts payable (Compustat item \#70) plus accrued expense (Compustat item \#153), respectively. DEPR is depreciation and amortization (Compustat item \#14). OTHER is calculated as EARN - (CFO $+\Delta \mathrm{AR}+\Delta \mathrm{INV}-\Delta \mathrm{AP}-\mathrm{DEPR})$.

\begin{tabular}{|c|c|c|c|c|c|c|c|c|}
\hline & EARN & $\mathrm{CFO}$ & ACCRUALS & $\Delta \mathrm{AR}$ & $\Delta \mathrm{INV}$ & $\Delta \mathrm{AP}$ & DEPR & OTHER \\
\hline EARN & & $0.55^{*}$ & $0.54 *$ & $0.21 *$ & $0.19 *$ & -0.001 & $-0.12^{*}$ & $0.24 *$ \\
\hline CFO & $0.52 *$ & & $-0.39 *$ & $-0.14^{*}$ & $-0.21 *$ & $0.03 *$ & $0.21 *$ & $-0.09 *$ \\
\hline ACCRUALS & $0.32 *$ & $-0.52 *$ & & $0.36^{*}$ & $0.42 *$ & $-0.04 *$ & $-0.35 *$ & $0.37 *$ \\
\hline$\Delta \mathrm{AR}$ & $0.27^{*}$ & $-0.12 *$ & $0.39 *$ & & $0.37 *$ & $0.41 *$ & -0.04 & $-0.33 *$ \\
\hline$\Delta \mathrm{INV}$ & $0.25 *$ & $-0.18 *$ & $0.45 *$ & $0.38 *$ & & $0.32 *$ & $-0.09 *$ & $-0.31 *$ \\
\hline$\Delta \mathrm{AP}$ & $0.11 *$ & $0.06^{*}$ & $-0.009 *$ & $0.32 *$ & $0.27 *$ & & 0.04 & $0.23 *$ \\
\hline DEPR & $-0.05^{*}$ & $0.29 *$ & $-0.42^{*}$ & $-0.05^{*}$ & $-0.10^{*}$ & $0.07 *$ & & $0.05 *$ \\
\hline OTHER & $0.09 *$ & $-0.09 *$ & $0.21 *$ & $-0.21^{*}$ & $-0.17 *$ & $0.41^{*}$ & $0.05 *$ & \\
\hline
\end{tabular}

* - Significant at 0.01 significance level for testing whether the correlation is different than zero 


\section{Table 4}

Descriptive Statistics on Level of Predictability, Proprietary Costs Proxies, and Variables used in Second Stage Analysis,

\section{Sample of 32,745 Firm-Year Observations, 1987-2000}

The table reports descriptive statistics on a sample of 32,745 firm-year observations. RES_ABS is equal to the absolute value of the residuals obtained from estimating equation (1). MARGIN is the year t net sales (Compustat item \#12) less cost of goods sold for the year (Compustat item \#41), scaled by net sales. OC

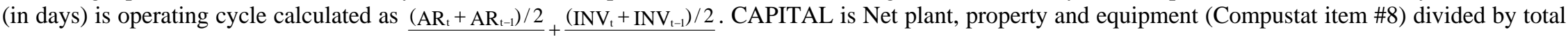
(Sales/360) $+\frac{(\mathrm{COGS} / 360)}{(\mathrm{IN})}$

assets (Compustat item \#6). SIZE is market capitalization at the end of the fiscal year (year t), calculated as the closing price at fiscal year-end times the number of shares outstanding at fiscal year-end (Compustat item \#199 times Compustat item\#25). MKT_BK is the market-to-book ratio, where market value of equity is calculated as the closing price at fiscal year-end times the number of shares outstanding at fiscal year-end (Compustat item \#199 times Compustat item \#25), divided by the book value of common equity (Compustat item \#60). GROWTH is current year's growth in sales, calculated as net sales for year $t$ (Compustat item \#12) less net sales of year t-1, scaled by net sales for year t-1. H1 is the Herfindahl Index and is calculated as the sum of squares of market shares in the industry. $\mathrm{H} 1=\sum_{\mathrm{i}=1}^{\mathrm{n}}\left[\mathrm{S}_{\mathrm{i}} / \mathrm{S}\right]^{2}$, where $\mathrm{S}_{\mathrm{i}}$ is the firm's sales and $\mathrm{S}$ is the sum of sales for all firms in the industry (defined by the 2-digit SIC code), and $\mathrm{n}$ is the number of firms in the industry.

\begin{tabular}{|c|c|c|c|c|}
\hline Variable & $\mathrm{N}$ & Mean & Median & Std Dev \\
\hline RES_ABS & 32,745 & 0.069 & 0.043 & 0.088 \\
\hline SIZE & 32,745 & 959.021 & 143.913 & 2445.051 \\
\hline MKT_BK & 32,745 & 2.883 & 1.773 & 58.263 \\
\hline MARGIN & 32,745 & 0.344 & 0.322 & 0.185 \\
\hline GROWTH & 32,745 & 0.069 & 0.082 & 0.515 \\
\hline CAPITAL & 32,745 & 0.333 & 0.275 & 0.227 \\
\hline H1 & 32,745 & 0.256 & 0.162 & 0.255 \\
\hline
\end{tabular}


Table 5

Summary Statistics from Regression of Future Cash Flow from Operations on Current Cash Flow from Operations and Components of Accruals, Sample of Compustat Firms 1987-2000

Regression summary statistics:

$$
\mathrm{CFO}_{\mathrm{i}, \mathrm{t}+1}=\alpha_{0}+\beta_{1} \mathrm{CFO}_{\mathrm{i}, \mathrm{t}}+\beta_{2} \Delta \mathrm{AR}_{\mathrm{i}, \mathrm{t}}+\beta_{3} \Delta \mathrm{INV}_{\mathrm{i}, \mathrm{t}}+\beta_{4} \Delta \mathrm{AP}_{\mathrm{i}, \mathrm{t}}+\beta_{5} \mathrm{DEPR}_{\mathrm{i}, \mathrm{t}}+\beta_{6} \mathrm{OTHER}_{\mathrm{i}, \mathrm{t}}+\varepsilon_{\mathrm{i}, \mathrm{t}+1}
$$

\begin{tabular}{lccc}
\hline Variable & Prediction & Coefficient & \multicolumn{1}{c}{ t-statistic } \\
\hline INTERCEPT & $?$ & 0.012 & $9.49^{* * *}$ \\
$\mathrm{CFO}_{\mathrm{t}}$ & + & 0.709 & $115.09^{* * *}$ \\
$\Delta \mathrm{AR}_{\mathrm{t}}$ & + & 0.396 & $39.10^{* * *}$ \\
$\Delta \mathrm{INV}_{\mathrm{t}}$ & + & 0.245 & $22.90^{* * *}$ \\
$\Delta \mathrm{AP}_{\mathrm{t}}$ & - & -0.326 & $-31.3^{* * *}$ \\
DEPR $_{\mathrm{t}}$ & + & 0.442 & $21.36^{* * *}$ \\
$\mathrm{OTHER}_{\mathrm{t}}$ & $?$ & 0.253 & $33.61^{* * *}$ \\
& & & \\
$\mathrm{~N}$ & 32,745 & & \\
Adj. $R^{2}$ & $\mathbf{0 . 3 2}$ & & \\
\hline
\end{tabular}

$* * *=$ two tailed probability $<0.01$

CFO is cash flow from operations (Compustat item \#308). $\Delta \mathrm{AR}, \Delta \mathrm{INV}, \Delta \mathrm{AP}$ are calculated as the change in the applicable balance sheet account, accounts receivable (Compustat item \#2), inventory (Compustat item \#3), and accounts payable (Compustat item \#70) plus accrued expense (Compustat item \#153), respectively. DEPR is depreciation and amortization (Compustat item \#14). OTHER is calculated as EARN $-(\mathrm{CFO}+\Delta \mathrm{AR}+\Delta \mathrm{INV}-\Delta \mathrm{AP}-\mathrm{DEPR})$.

All variables are deflated by average total assets. 


\section{Table 6}

\section{Correlation matrix between explanatory variables used to explain predictability}

This table reports Pearson (above the diagonal) and Spearman correlations (below the diagonal). The sample is based on 32,745 firm-year observations (given data availability). RES_ABS is equal to the absolute value of the residuals obtained from estimating equation (1). MARGIN is gross margin percentage, defined as the year $t$ net sales less cost of goods sold, scaled by net sales. CAPITAL is defined as Net plant, property and equipment divided by total assets, and is calculated as Compustat item \#8 / Compustat item \#6. MKT_BK is the market-to-book ratio, where market value of equity is calculated as the closing price at fiscal year-end times the number of shares outstanding at fiscal year-end (Compustat item \#199 times Compustat item \#25), divided by the book value of common equity (Compustat item \#60). SIZE is market capitalization and is calculated as natural logarithm of the closing price at fiscal year-end times the number of shares outstanding at fiscal year-end (Compustat item \#199*Compustat item \#25). H1 is the Herfindahl Index and is calculated as the sum of squares of market shares in the industry. $\mathrm{H} 1=\sum_{\mathrm{i}=1}^{\mathrm{n}}\left[\mathrm{S}_{\mathrm{i}} / \mathrm{S}\right]^{2}$, where $\mathrm{S}_{\mathrm{i}}$ is the firm's sales and $\mathrm{S}$ is the sum of sales for all firms in the industry (defined by the SIC code), and $\mathrm{n}$ is the number of firms in the industry. OC is operating cycle (in days), calculated as $\frac{\left(\mathrm{AR}_{\mathrm{t}}+\mathrm{AR}_{\mathrm{t}-1}\right) / 2}{(\mathrm{Sales} / 360)}+\frac{\left(\mathrm{INV}_{\mathrm{t}}+\mathrm{INV}_{\mathrm{t}-1}\right) / 2}{(\mathrm{COGS} / 360)}$.

\begin{tabular}{lrrrrrrrr}
\hline & RES_ABS & MARGIN & H1 & GROWTH & CAPITAL & SIZE & MKT_BK & OC \\
\hline RES_ABS & & $0.06^{*}$ & $0.02^{*}$ & $0.05^{*}$ & $-0.22^{*}$ & $-0.16^{*}$ & $0.14^{*}$ & $0.06^{*}$ \\
MARGIN & $0.06^{*}$ & & $0.02^{*}$ & $0.02^{*}$ & $-0.12^{*}$ & $0.13^{*}$ & $0.016^{*}$ & $0.29^{*}$ \\
H1 & $0.01^{*}$ & $0.02^{*}$ & & 0.000 & $0.05^{*}$ & $0.04^{*}$ & -0.003 & $0.01^{* *}$ \\
GROWTH & $0.14^{*}$ & $0.10^{*}$ & $0.04^{*}$ & & -0.000 & $0.07^{*}$ & 0.008 & $-002^{*}$ \\
CAPITAL & $-0.26^{*}$ & $-0.16^{*}$ & $0.13^{*}$ & $-0.11^{*}$ & & $0.21^{*}$ & -0.008 & $-0.35^{*}$ \\
SIZE & $-0.21^{*}$ & $0.14^{*}$ & $0.06^{*}$ & $0.13^{*}$ & $0.22^{*}$ & & 0.008 & $-0.07^{*}$ \\
MKT_BK & $0.12^{*}$ & $0.27^{*}$ & 0.05 & $0.32^{*}$ & $-0.08^{*}$ & $0.21^{*}$ & & -0.001 \\
OC & $0.12^{*}$ & $0.26^{*}$ & $0.19^{*}$ & $0.04^{*}$ & $-0.36^{*}$ & $-0.10^{*}$ & -0.007 & \\
\hline
\end{tabular}

*,** - Significant at 0.01, 0.05 significance level, respectively for testing whether the correlation is different than zero 
Table 7

Summary statistics from regression of absolute value of residuals from (1) on various factors determining variation in cash flow predictability, Sample of Compustat Firms 1987-2000

$$
\begin{gathered}
\left|e_{i, t+1}\right|=\phi_{0}+\phi_{1} \operatorname{SIZE}_{i, t}+\phi_{2} \text { MARGIN }_{i, t}+\phi_{3} \text { CAPITAL }_{i, t}+\phi_{4} \text { GROWTH }_{i, t}+\phi_{5} H 1_{i, t}+ \\
+\phi_{6} \mathrm{OC}_{\mathrm{i}, \mathrm{t}}+\phi_{7} \mathrm{MKT}_{-} \mathrm{BK}_{\mathrm{i}, \mathrm{t}}+\xi_{\mathrm{i}, \mathrm{t}+1}
\end{gathered}
$$

\begin{tabular}{|c|c|c|}
\hline Variable & Prediction & $\begin{array}{c}\text { Coefficient } \\
\text { (t - statistic) }\end{array}$ \\
\hline INTERCEPT & ? & $\begin{array}{c}-2.98 \\
(-13.08)^{* * *}\end{array}$ \\
\hline $\mathrm{SIZE}_{\mathrm{i}, \mathrm{t}}$ & - & $\begin{array}{c}-0.11 \\
(-31.13)^{* * *}\end{array}$ \\
\hline MARGIN $_{i, t}$ & + & $\begin{array}{c}0.41 \\
(10.55)^{* * *}\end{array}$ \\
\hline CAPITAL $_{i, t}$ & - & $\begin{array}{c}-1.21 \\
(-36.41)^{* * *}\end{array}$ \\
\hline $\mathrm{GROWTH}_{\mathrm{i}, \mathrm{t}}$ & + & $\begin{array}{c}0.13 \\
(9.52)^{* * *}\end{array}$ \\
\hline $\mathrm{MKT}_{-} \mathrm{BK}_{\mathrm{i}, \mathrm{t}}$ & + & $\begin{array}{c}0.0002 \\
(2.24)^{* *}\end{array}$ \\
\hline $\mathrm{H} 1_{\mathrm{i}, \mathrm{t}}$ & $-/+$ & $\begin{array}{c}1.50 \\
(7.71)^{* * *}\end{array}$ \\
\hline $\mathrm{OC}_{\mathrm{i}, \mathrm{t}}$ & + & $\begin{array}{c}0.0005 \\
(8.13)^{* * *}\end{array}$ \\
\hline $\mathbf{N}$ & & 32,676 \\
\hline Adj. $R^{2}$ & & 0.29 \\
\hline
\end{tabular}

$* *, * * *=$ two tailed probability $<0.05$, two tailed probability $<0.01$

Column B represents the results of estimating (2a) with industry dummies and year dummies. 
Table 8

Summary statistics from regression of standard deviation of residuals on various factors determining variation in cash flow predictability, Sample of 1,255 Compustat Firms 1987-2000

(2b) $\sigma_{\mathrm{e}_{\mathrm{i}}}=\phi_{0}+\phi_{1} \mathrm{SIZE}_{\mathrm{i}}+\phi_{2}$ MARGIN $_{\mathrm{i}}+\phi_{3} \mathrm{CAPITAL}_{\mathrm{i}}+\phi_{4} \mathrm{GROWTH}_{\mathrm{i}}+\phi_{5} \mathrm{H}_{\mathrm{i}}+$ $+\phi_{6} \mathrm{OC}_{\mathrm{i}}+\phi_{7} \mathrm{MKT}_{-} \mathrm{BK}_{\mathrm{i}}+\xi_{\mathrm{i}}$

\begin{tabular}{|c|c|c|}
\hline Variable & Prediction & $\begin{array}{l}\text { Coefficient } \\
\text { (t - statistic) }\end{array}$ \\
\hline INTERCEPT & $?$ & $\begin{array}{c}0.050 \\
(20.23)^{* * *}\end{array}$ \\
\hline $\mathrm{SIZE}_{\mathrm{i}, \mathrm{t}}$ & - & $\begin{array}{c}-0.004 \\
(-13.16)^{* * *}\end{array}$ \\
\hline MARGIN $_{\mathrm{i}, \mathrm{t}}$ & + & $\begin{array}{c}0.017 \\
(3.83)^{* * *}\end{array}$ \\
\hline CAPITAL $_{\mathrm{i}, \mathrm{t}}$ & - & $\begin{array}{c}-0.032 \\
(-9.56)^{* * *}\end{array}$ \\
\hline $\mathrm{GROWTH}_{\mathrm{i}, \mathrm{t}}$ & + & $\begin{array}{c}0.011 \\
(1.92)^{* *}\end{array}$ \\
\hline $\mathrm{MKT}_{-} \mathrm{BK}_{\mathrm{i}, \mathrm{t}}$ & + & $\begin{array}{l}0.0027 \\
(1.71)^{*}\end{array}$ \\
\hline $\mathrm{H} 1_{i, t}$ & $-/+$ & $\begin{array}{l}0.026 \\
(1.25)\end{array}$ \\
\hline $\mathrm{OC}_{\mathrm{i}, \mathrm{t}}$ & + & $\begin{array}{l}0.00001 \\
(2.20)^{* *}\end{array}$ \\
\hline $\mathbf{N}$ & & 1,255 \\
\hline Adj. $R^{2}$ & & 0.33 \\
\hline
\end{tabular}

$*$, **, $* * *=$ two tailed probability $<0.10$, two tailed probability $<0.05$, two tailed probability $<0.01$ 
Table 9

Summary statistics from regression of absolute value of residuals from (1) on various factors determining variation in cash flow predictability

Sample of Compustat Firms 1987-2000

$$
\begin{gathered}
\left|e_{i, t+j}\right|=\phi_{0}+\phi_{1} \operatorname{SIZE}_{i, t}+\phi_{2} \operatorname{MARGIN}_{i, t}+\phi_{3} \text { CAPITAL }_{i, t}+\phi_{4} \text { GROWTH }_{i, t}+ \\
+\phi_{5} \mathrm{H}_{\mathrm{i}, \mathrm{t}}+\phi_{6} \mathrm{OC}_{\mathrm{i}, \mathrm{t}}+\phi_{7} \mathrm{MKT}_{-} \mathrm{BK}_{\mathrm{i}, \mathrm{t}}+\xi_{\mathrm{i}, \mathrm{t}+\mathrm{j}}
\end{gathered}
$$

A

B

\begin{tabular}{|c|c|c|c|}
\hline Variable & Prediction & $\begin{array}{c}\text { Coefficient } \\
\text { (t - statistic) }\end{array}$ & $\begin{array}{l}\text { Coefficient } \\
\text { (t-statistic) }\end{array}$ \\
\hline INTERCEPT & ? & $\begin{array}{c}-2.79 \\
(-11.95) * * *\end{array}$ & $\begin{array}{c}-2.65 \\
(-11.55) * * *\end{array}$ \\
\hline $\mathrm{SIZE}_{\mathrm{i}, \mathrm{t}}$ & - & $\begin{array}{c}-0.117 \\
(-27.80)^{* * *}\end{array}$ & $\begin{array}{c}-0.113 \\
(-24.06)^{* * *}\end{array}$ \\
\hline MARGIN $_{i, t}$ & + & $\begin{array}{c}0.375 \\
(8.08) * * *\end{array}$ & $\begin{array}{c}0.484 \\
(9.04)^{* * *}\end{array}$ \\
\hline CAPITAL $_{\mathrm{i}, \mathrm{t}}$ & - & $\begin{array}{c}-0.746 \\
(-17.08)^{* * *}\end{array}$ & $\begin{array}{c}-0.645 \\
(-13.40)^{* * *}\end{array}$ \\
\hline $\mathrm{GROWTH}_{\mathrm{i}, \mathrm{t}}$ & + & $\begin{array}{c}0.091 \\
(5.02)^{* * *}\end{array}$ & $\begin{array}{c}0.132 \\
(6.26)^{* * *}\end{array}$ \\
\hline $\mathrm{MKT}_{-} \mathrm{BK}_{\mathrm{i}, \mathrm{t}}$ & + & $\begin{array}{c}0.007 \\
(2.74)^{* * *}\end{array}$ & $\begin{array}{c}0.001 \\
(3.27)^{* * *}\end{array}$ \\
\hline $\mathrm{H} 1_{\mathrm{i}, \mathrm{t}}$ & $-/+$ & $\begin{array}{c}1.12 \\
(5.27)^{* * *}\end{array}$ & $\begin{array}{c}1.33 \\
(5.9)^{* * *}\end{array}$ \\
\hline $\mathrm{OC}_{\mathrm{i}, \mathrm{t}}$ & + & $\begin{array}{c}0.0001 \\
(2.45)^{* * *}\end{array}$ & $\begin{array}{c}0.00002 \\
(0.34)\end{array}$ \\
\hline $\mathbf{N}$ & & 26,834 & 21,841 \\
\hline Adj. $R^{2}$ & & 0.25 & 0.18 \\
\hline
\end{tabular}

$\left|e_{i, t+2}\right| \quad\left|e_{i, t+3}\right|$

$* *, * * *=$ two tailed probability $<0.05$, two tailed probability $<0.01$ 
Table 10

Summary statistics from regression of standard deviation of residuals on various factors determining variation in cash flow predictability, Sample of 1,255 Compustat Firms 1987-2000

$$
\begin{aligned}
\sigma_{\mathrm{e}_{\mathrm{i}+\mathrm{j}}}=\phi_{0} & +\phi_{1} \mathrm{SIZE}_{\mathrm{i}}+\phi_{2} \text { MARGIN }_{\mathrm{i}}+\phi_{3} \text { CAPITAL }_{\mathrm{i}}+\phi_{4} \mathrm{GROWTH}_{\mathrm{i}}+ \\
& +\phi_{5} \mathrm{H}_{\mathrm{i}}+\phi_{6} \mathrm{OC}_{\mathrm{i}}+\phi_{7} \mathrm{MKT}_{-} \mathrm{BK}_{\mathrm{i}}+\xi_{\mathrm{i}+\mathrm{j}}
\end{aligned}
$$

\begin{tabular}{|c|c|c|c|}
\hline & & A & B \\
\hline Variable & Prediction & $\begin{array}{c}\text { Coefficient } \\
\text { (t - statistic) }\end{array}$ & $\begin{array}{l}\text { Coefficient } \\
\text { (t-statistic) }\end{array}$ \\
\hline INTERCEPT & $?$ & $\begin{array}{c}0.049 \\
(13.79)^{* * *}\end{array}$ & $\begin{array}{c}0.04 \\
(11.26)^{* * *}\end{array}$ \\
\hline $\mathrm{SIZE}_{\mathrm{i}, \mathrm{t}}$ & - & $\begin{array}{c}-0.003 \\
(-7.47)^{* * *}\end{array}$ & $\begin{array}{c}-0.003 \\
(-6.91)^{* * *}\end{array}$ \\
\hline MARGIN $_{\mathrm{i}, \mathrm{t}}$ & + & $\begin{array}{l}0.001 \\
(0.96)\end{array}$ & $\begin{array}{c}0.014 \\
(2.05)^{* *}\end{array}$ \\
\hline CAPITAL $_{\mathrm{i}, \mathrm{t}}$ & - & $\begin{array}{c}-0.03 \\
(-5.27)^{* * *}\end{array}$ & $\begin{array}{c}-0.026 \\
(-5.22)^{* * *}\end{array}$ \\
\hline $\mathrm{GROWTH}_{\mathrm{i}, \mathrm{t}}$ & + & $\begin{array}{c}0.035 \\
(4.04)^{* * *}\end{array}$ & $\begin{array}{c}0.046 \\
(5.21)^{* * *}\end{array}$ \\
\hline $\mathrm{MKT}_{-} \mathrm{BK}_{\mathrm{i}, \mathrm{t}}$ & + & $\begin{array}{c}0.006 \\
(2.64)^{* * *}\end{array}$ & $\begin{array}{l}0.003 \\
(1.52)\end{array}$ \\
\hline $\mathrm{H} 1_{\mathrm{i}, \mathrm{t}}$ & $-/+$ & $\begin{array}{c}0.053 \\
(1.74)^{*}\end{array}$ & $\begin{array}{c}0.021 \\
(1.81)^{*}\end{array}$ \\
\hline $\mathrm{OC}_{\mathrm{i}, \mathrm{t}}$ & + & $\begin{array}{c}0.00001 \\
(1.06)\end{array}$ & $\begin{array}{c}0.00001 \\
(1.12)\end{array}$ \\
\hline $\mathbf{N}$ & & 1,255 & 1,255 \\
\hline Adj. $R^{2}$ & & 0.22 & 0.19 \\
\hline
\end{tabular}

$*$, **, $* * *=$ two tailed probability $<0.10$, two tailed probability $<0.05$, two tailed probability $<0.01$

Column A represents the results of estimating (2b) for the prediction of $\mathrm{CF}_{\mathrm{t}+2}$

Column B represents the results of estimating (2b) for the prediction of $\mathrm{CF}_{\mathrm{t}+3}$ 